\title{
Relations Between Singapore and the People's Republic of China in the Light of Donald Trump's New Southeast Asia Policy
}

\author{
Mateusz Chatys \\ University of Lodz \\ Faculty of International and Political Studies \\ Department of Asian Studies \\ e-mail: mateusz.chatys@uni.lodz.pl
}

\section{Abstract}

The aim of the article is to analyze the relationship between Singapore and the People's Republic of China in the light of the current policy of the President of the United States Donald Trump. The point of reference for the presented analysis is the foreign policy of the former President Barack Obama, based on the strategy known as "pivot to Asia" - the strategic turnabout of the United States to the Asia-Pacific region. One of its main objectives was the signing of a multilateral agreement on the establishment of a free trade zone, the Trans-Pacific Partnership (TPP), bringing together 12 countries. The main subject of the present analysis is to examine the impact of Donald Trump's decision of January 2017 to withdraw from the TPP trade agreement on the relations between the remaining signatories of the agreement, as well as to examine Beijing's actions, which may seek to increase its sphere of influence in Asia through the breakdown of TPP. The main part of the research is focused on the triangle politics concept in international politics, which will include China, Singapore and the United States. Besides the two largest economic powers, Singapore is included because of its membership in the TPP and ASEAN, and due to its strong economy and its population (predominantly) of Chinese origin it can be viewed as the "fifth column" or may otherwise play a role in the Greater China concept.

Keywords: China, USA, Singapore, Southeast Asia, pivot to Asia, Donald Trump, Trans-Pacific Partnership (TPP), Association of South-East Asian Nations (ASEAN). 


\section{Introduction}

The aim of the article is to discuss and analyze the relationship between Singapore and the People's Republic of China in the light of the policy of the President of the United States Donald Trump. The point of reference for this analysis is the foreign policy of former President Barack Obama, based on the strategy known as Pivot to Asia - the strategic return of the United States to the Asia-Pacific region. One of its main elements was the signing of a multilateral agreement on the establishment of a free trade zone on October 5, 2015, the Trans-Pacific Partnership (TPP), bringing together 12 countries. Therefore, the main subject of the analysis is to examine what impact Donald Trump's decision to withdraw from the TPP in January 2017 is going to have on the relations between the remaining signatories of the agreement, as well to examine Beijing's own policy.

In this article, I present the following research hypothesis: the withdrawal of the US from the TPP, as well as the way in which Donald Trump chooses to neutralize a nuclear threat from North Korea, is being used by the Chinese authorities to increase China's sphere of economic and military influence in the South East Asia region.

The decision of the United States to exit from the Trans-Pacific Partnership undoubtedly testifies to its increasing economic protectionism, which results in the withdrawal from multilateral agreements in favor of a greater number of bilateral agreements. In addition, tensions between Washington and Pyongyang may result in a shrinking of American economic activity in the Asia region in favor of an increased military presence. Of course, the last US-North Korea summit in Singapore in June 2018 has stabilized relations between the states, but there is still a long way to go before friendly relations between the two countries can be established.

The main part of the research is based on the triangle politics concept in international politics, which will include China, Singapore and the United States. In addition to the two greatest economic powers, there is also Singapore. It is a member of both the TPP and ASEAN, and due to its strong economy and predominantly Chinese population it can be described as the fifth column or the next component of Greater China. On the basis of the theoretical part thus formulated, a comparative analysis of mutual relations between these countries will be presented, which in turn will allow conclusions to be drawn regarding the future of the TPP as well as the outlook for economic dominance in Asia in the coming years.

\section{Donald Trump's new policy characteristics}

During the presidential campaign for the highest office in the US between Hillary Clinton and Donald Trump many controversial declarations were made. To a large extent, they were related to the future US foreign policy, in which the Asia region 
was supposed to play a dominant role. One of the main demands of the Republican Party candidate was the withdrawal of the United States from the TransPacific Partnership, which he believed would provide greater security for American economy and workplaces. An additional electoral advantage of this promise was the discrediting of foreign policy led by then-President Barack Obama, member of the same political party as Hillary Clinton, who was Obama's first Secretary of State from 2009 to 2013. Moreover, she was the main architect of the US foreign policy in Asia.

Views presented by Donald Trump regarding the TPP were widely supported by the American citizens. At the same time, they caused a great concern among Asian countries, especially those less economically developed or with less military potential. In contrast to the foreign policy of President Obama, who early during his term was being described as "the first American president of the Pacific Ocean." During his first visit to Tokyo in 2009, he focused on the greater involvement of the US in the Asia-Pacific region. From this moment, the term pivot to Asia gained currency in American foreign policy, although it was first used by Hillary Clinton in her article titled America's Pacific Century, published in "Foreign Policy" in 2011 (Clinton). Paradoxically, despite significant ideological differences between Trump and Obama, their actions at the beginning of their respective terms are comparable. When President Obama took office on January 20, 2009, he declared his intention to limit US activity in the Middle East, on which the foreign policy of George W. Bush's administration was largely focused.

The most important project within the framework of pivot to Asia was the creation of a regional, multilateral economic agreement aimed at balancing the Chinese influence (in the era of rapid economic development) in South East Asia. Especially since as of 2009 the United States had Free Trade Agreements (FTAs) signed with only two countries of the Asia-Pacific region, namely Singapore (6.05.2003) and Australia (18.05.2004). The TPP consisted of 12 countries: Australia, Brunei, Canada, Chile, Japan, Malaysia, Mexico, New Zealand, Peru, Singapore, the United States and Vietnam. Talks on its creation began already in 2008 (George W. Bush initiated the first negotiations on the multilateral format of economic cooperation close to the end of his term, but it is Barack Obama who is considered as the author of this initiative). However, on January 23, 2017 (only three days after he was sworn into office), Donald Trump signed a decree on the withdrawal of the US from the TPP. His main arguments for leaving the treaty were:

- protecting workplaces in the US,

- stopping the outflow of capital from the state,

- inflow of cheaper and often subsidized goods from Asia while maintaining barriers to US export,

- the possibility of China's interference in the US market via TPP countries,

- the threat of manipulation of the Japanese currency (Allison, 7). 
Trump therefore claimed that bilateral agreements with individual countries in the region would be better for the state's investment needs, while protecting the internal market against the negative aspects related to cooperation with eastern partners (e.g., dumping). During the election campaign, this kind of protectionist rhetoric gave Trump considerable public support. However, the biggest surprise was that Hillary Clinton, who had significantly contributed to the establishment of the TPP as the Secretary of State at the beginning of negotiations, began to change her position during the campaign, then claiming that she was willing to withdraw from the partnership if it posed a threat to American jobs or proved to have a negative impact on wages. Of course, it is necessary to take political declarations with a grain of salt, especially those made during the election campaign. The leaders of the Asian region were aware of this and, nevertheless, remained more confident in the cooperation with the Democratic candidate (China being an obvious exception), whom they saw as more predictable. This situation is well demonstrated by the drop of key indices immediately after the election results were announced: Japanese Nikkei 225 lost 5.4\%, Hang Seng in Hong Kong dropped by $2.2 \%$, Shanghai Composite by $0.6 \%$, Australian ASX by $1.9 \%$ and South Korean Kospi by $2.7 \%$ (US Election 2016: Asia markets jolted by Trump win, 2016).

Considering the culture of the Far East, both candidates were negatively perceived in terms of the image of the United States as a state. The Trans-Pacific Partnership was mainly an American initiative, which is why America's withdrawal from it during the final phase of the arrangements and the sudden change of Hillary Clinton's opinion were perceived by some partners as a kind of loss of face. Naturally, this aspect probably will not have a noticeable impact on trade relations or political relations with the US, because it is a superpower with a strong economy that is needed by other countries in economic development, but China will certainly use it to further its own propaganda and promote solutions such as the Regional Comprehensive Economic Partnership (RCEP).

Donald Trump is aware of Asia's growing role in the global market - not only due to the rising power of China, but also to such countries as Singapore, which have a huge economic potential. Additionally, unresolved disputes in the South China Sea, ${ }^{1}$ missile tests and the nuclear threat from North Korea, as well as a treaty on mutual cooperation and security with Japan require a military presence in the region. Due to all these factors, in November 2017 Donald Trump undertook one of the longest presidential trips to Asia in many years. In 12 days, he visited five

1 Disputes concern the archipelago of the Spratly Islands, to which China, Philippines, Brunei, Vietnam and Malaysia stake claim, as well as the archipelago of the Paracele Islands, claimed by China, Vietnam and Taiwan. Most of them are controlled by the PRC, due to the gradual occupation due to the "salami slicing" strategy and the "cabbage" strategy. These policies consist in gradually taking control of subsequent islands and atolls, as well as effectively blocking other ships' access to the islands. 
countries (Japan, South Korea, China, Vietnam and the Philippines), taking part in the APEC summit at Danang and the 31st ASEAN Summit in Manila, during which Singapore officially took over the presidency of ASEAN for one-year term in 2018 (previously this function was performed by the Philippines). According to the official statement, as a result of delays related to organizational work, President Trump did not take part in the 12th East Asia Summit, in which the United States was represented by Secretary of State Rex Tillerson (Holland). Thereafter it was easy to conclude that the countries of Southeast Asia (ASEAN) are of secondary importance in American politics. The next summit took place in November 2018 in Singapore and, the US were represented by the Vice-President Mike Pence. The East Asian Summit is an extremely important platform for international dialogue, in which 18 national leaders take part (aside from the US, representatives of China and Singapore also participate) ${ }^{2}$. Since 2005 the biggest beneficiaries of the summit have been countries with the least military and economic potential, as the forum offers them a platform to speak on key issues related to regional security, and be heard by the superpowers (Bisley, 1-3). From the perspective of developing countries, stability in the region is a crucial factor, which enables sustainable economic progress.

One of the main reasons for Donald Trump's long journey to Asia was, in a way, to compensate countries involved in the Trans-Pacific Partnership for withdrawing from the treaty. Furthermore, the visit was intended to dispel all doubts regarding the America first political strategy, ${ }^{3}$ which caused concern not only about economic protectionism, but also about the future of American military bases and US military involvement in Asia. This was connected with the statements of the Republican president regarding the need to focus on the US internal situation. In his opinion, allies of the US should devote more resources to their defense capabilities, if they expect to see America's cooperation on the same level in this area. Besides the military bases in Japan and South Korea, Americans are also present in the Philippines and in Thailand. Singapore does not host US bases as such, but under an agreement signed in 1990, the US Navy can use Singapore's ports, and there is a logistics unit on site (Factsheet - The Strategic Framework Agreement, 2005). In the era of threats from North Korea, both Japan and South Korea have received strong support and assurance that in case of aggression by Kim Jong Un, American armed forces will be involved. However,

2 Apart from such superpowers as China, USA, Russia or India, the summit also included countries like Australia, New Zealand, Japan, South Korea, Indonesia, Malaysia, Brunei, Laos, Burma, Thailand, Cambodia, Philippines, Singapore and Vietnam.

3 Donald Trump first used this phrase in March 2016 in an interview for The New York Times, when he answered a question about his views on isolationism. He stated then that he is not an advocate of isolationism, but America is the most important ("I'm not isolationist, but I am 'America First'"). This slogan arouses much controversy due to the fact that in 1940 the organization The America First Committee opposed the participation of American troops in World War II and was critical of President Roosevelt and his administration (Calamur 2017). 
strained relations with the North Korean regime have somehow overshadowed disputes in the South China Sea that have remained unresolved for 60 years. For instance, despite the fact that the Philippines reported the issue of disputed islands with China to the Permanent Court of Arbitration, and a verdict was issued in July 2016 in favor of the Philippines, China still controls most of the South China Sea and its natural resources. Chinese government at the very beginning of the trial announced that it would not recognize any decision issued by this authority, and thus would continue to exercise control over the acquired area along the demarcation line (the so-called nine-dash line), designated in 1947 by the Chinese authorities (Perlez).

President Trump, during his last visit to Vietnam, which is also one of the parties to the conflict over the islands, announced that he would participate in mediations on disputed territories. Given that these matters have not been resolved for so many years, it is obvious that mediation probably will not be enough to resolve such a complex situation. Especially as China, under the pretext of developing a Code of Conduct ${ }^{4}$ in South China Sea, continues establishing new artificial islands and erects military installations on them. It could thus reasonably be assumed that the limited American involvement in this matter is the result of arrangements with China, which, in exchange for influence in the South China Sea, will exert more pressure and strictly follow the embargo imposed on the North Korean regime.

Careful analysis of the ASEAN leaders' summit in Manila makes clear that the current US president's approach to human rights is radically different from that of his predecessor. This is evidenced by Trump's meeting with the President of the Philippines, Rodrigo Duterte, who is known for his radical views, as well as his strong-minded fight against drug-related crimes in the country. Donald Trump focused on enhancing bilateral relations between the two states, completely ignoring the internal situation in the Philippines. China may see this as a signal that it can act more decisively not only in internal matters, but also outside the state, for example on the South China Sea. What is more, other countries in the region may become radicalized, such as Cambodia, where Prime Minister Hun Sen, through the Supreme Court, dissolved the largest opposition party (Cambodia National Rescue Party) in order to secure a win in parliamentary elections in July 2018 (Holmes). Cambodia's ruling Cambodian People's Party (CPP) won all 125 parliamentary seats in a national election. Due to these circumstances, Chinese sphere of influence in such areas as military (military bases in the South China Sea), ideology (communism in Cambodia) and economy (the "Belt and Road" initiative and the Regional Comprehensive Economic Partnership) is free to spread throughout Asia.

4 Work on the document began in 1990, but the Declaration on the Proceedings in the South China Sea between China and ASEAN, signed in 2002, was not legally binding. Since then, negotiations on the final version of this document have been held at the ASEAN + China summits, but Chinese government has so far been successful in drawing out the work. (YingHui 2017). 


\section{Political and economic relations in the triangle China, Singapore, the United States}

The concept of a strategic triangle, which is a tool for analyzing the relations between the three actors, was first introduced by Lowell Dittmer in his scientific article published in Word Politics, entitled "The Strategic Triangle: An Elementary Game-Theoretical Analysis.” In his deliberations Dittmer presented three types of relationships: a romantic triangle, a stable marriage, and a strategic triangle (Basaldú, 4). The first two examples describe the cooperation between three entities depending on their relationship. That is why a romantic triangle occurs when two entities, individually, have a good relationship with the third one, but they cannot agree among themselves. In the second case, there are good relations between the first two entities, but they do not have a good relation with third one. According to Herbert Ellison, the strategic triangle concept is a kind of game, which takes place between three actors who adapt their actions to specific situations. This kind of dynamics can be observed among China, the US and Singapore (Woo, 34-36). These tripartite relations are determined to a large extent by bilateral relations between each of the parties, as well as the conditions of the environment within in which they operate.

The normalization of relations between Beijing and Washington has a long history, beginning with the 1972 visit of President Richard Nixon to China. Since then, ideological competition has turned into economic rivalry due to economic reforms implemented by Deng Xiaoping. It should not come as a surprise that most of the accusations against China have economic background. The most important of them include the manipulation of the national currency (yuan), the inflow of statesubsidized goods, which leads to price dumping, intellectual property theft and illegal economic immigration. During the presidential campaign, Donald Trump announced that he would make every effort to create a better environment for American entrepreneurs at home, to encourage them to bring their factories back from China to the United States. He even declared the implementation of $45 \%$ duty on goods imported from China. These statements were the first signs of an upcoming trade war between the two largest economies in the world, which we can now observe. Already as a president elect, Donald Trump caused a diplomatic scandal at the beginning of December 2016, due to a telephone conversation with Tsai Ingwen, acting president of Taiwan at the time (Blanchard) ${ }^{5}$.

After Trump was sworn in, North Korea increased its military activity, which led to the softening of Trump's rhetoric towards China, while awaiting Beijing's greater

5 It was the first such conversation since 1979, when President Jimmy Carter suspended formal diplomatic relations with Taiwan. 
commitment to compliance with sanctions (especially oil) imposed by the UN Security Council under the regime of Kim Jong Un. Trump's visit to Beijing showed a completely different face than the one he used during the presidential campaign. Apart from image-related issues, there are also measurable effects of this trip, for example in the form of trade agreements valued at $\$ 250$ billion and concerning such products as integrated circuits, jet engines and car parts (US and China sign trade deals worth $\$ 250$ bn on Trump trip as he vows to change 'unfair' relationship, 2017). Such agreements are very much needed by the US economy, since the trade balance with China has been negative for the last several years. As the data provided by the Census office shows, in 2017 the deficit amounted to $\$ 344$ billion so there was an improvement compared to 2016 (Trade in Goods with China 2017). In addition, according to data from October 2017, US debt to China is $\$ 1.2$ trillion, which is about $19 \%$ from $\$ 6.3$ trillion in Treasury bills and bonds held by foreign countries (Mullen). This is also to Beijing's advantage, because it can threaten the US government that through the sudden sale of a large debt package will cause inflation to rise, and thus slow down economic development.

Considering the bilateral relations, leaving the TPP by the United States should have a long-term positive impact on the relations between the two powers. Barack Obama did not hide the fact that development of the partnership was largely determined by China's growing potential in the region, and its most important task was to counterbalance these influences, especially since they are systematically increased thanks to the implementation of the projects included in "One Belt One Road" initiative, announced by Xi Jinping in September 2013. It includes the New Silk Road and the 21st Century Maritime Silk Road, which are land and maritime transport routes, aimed at the development of infrastructure and logistics between China, Africa and Europe, in order to improve economic and cultural cooperation (Belt and Road Basics).

Singapore gained independence in 1965 and established formal diplomatic relations with the United States a year later. Thanks to the fast signing of the bilateral free trade agreement in 2003, the dynamic development of Singapore was possible, whose GDP per capita at the beginning was less than \$320, while in March 2017 it amounted to $\$ 60$ thousand (Zhou). According to a report published by The Heritage Foundation, it enjoys the highest economic freedom index (Miller, 4), thanks to which many multinational corporations have their branches here, which generates a large amount of Foreign Direct Investment (FDI). The biggest source of FDIs in Singapore is the United States. In addition, they come fifth in terms of export and third in terms of import, which results in a negative trade balance for an Asian country amounting to $\$ 8$ billion (Singapore: Trade Statistics).

The large number of investments and the growing economy are the reason why in Singapore there are ports with the highest traffic volume, therefore the sea transport routes in the South China Sea are of great strategic importance for this 
country. In turn, the decreasing US involvement in the region may lead to the country's dependence on Chinese influence related to the control of the entire basin. Of course, the US Navy also operates there, for example within a program Freedom of Navigation Operation (FONOP), but the effectiveness of China's strategies, as well as the threat posed by North Korea, make this problem unresolved (Gady). The US and Singapore are also signatories of bilateral agreements in the field of military cooperation. The last one was signed in December 2015 (Enhanced Defense Cooperation Agreement) and concerns military, strategic and technological cooperation as well as combating unconventional threats, including piracy and international terrorism (Defense Cooperation).

Leaving TPP by the United States has led to regional imbalances. Then, absence of the greatest power in a multilateral initiative of this kind will prevent it from fulfilling its most important function, which was to balance the Chinese influence. Originally, all members of the partnership represented $40 \%$ of global GDP and $20 \%$ of trade volume, but the US accounted for $69 \%$ of the GDP of the entire group. Thus, regardless of whether or not the other 11 countries come to an agreement, the main beneficiary of Donald Trump's decision is China. The breakthrough moment for the future of the partnership will come in at the beginning of 2019, because at that time final arrangements are supposed to be agreed upon regarding the Comprehensive and Progressive Agreement for Trans-Pacific Partnership (CPTPP). In November 2018 Vietnam's lawmaking body, the National Assembly ratified a landmark 11-country deal CPTPP, which makes Vietnam the seventh country after Australia, Canada, Japan, Singapore, Mexico and New Zealand who accepted the terms of this free trade agreement $(\mathrm{Vu})$.

After all, the comment by Singapore Prime Minister Lee Hsien Loong regarding changes in the TPP is very accurate: "It doesn't mean that the existing trade stops, it doesn't mean that investment flows are abandoned" (Chadran). Singapore has been in good relations with the USA for over 50 years and, in addition, it has entered into an Economic Partnership Agreement with Japan and Australia, as well as FTAs with South Korea and New Zealand, which are the most significant TPP members in economic terms (Singapore Free Trade Agreements). Donald Trump's decision to abandon the partnership will negatively affect the least-developed countries (Vietnam, Brunei, Malaysia), and thus it is very likely that Chinese influence, due to various kinds of non-returnable loans and preferential credit lines for infrastructure investments, will have a major impact not only on economic progress, but also on social anxieties in certain countries, which is an important factor for any government trying to stay in power.

Relations between China and Singapore predate even the founding of the People's Republic of China in 1949, because many Chinese fled the unstable situation on the continent to what was then a British colony. This is the main reason why the vast majority of Singaporeans are ethnically Chinese (Population Trends). 
The other reason for Chinese ethnic domination may be the use of the so-called fifth column strategy, which dates back to the Spanish Civil War in the early $20^{\text {th }}$ century (Britannica). It consisted in placing spies in the enemy camp, whose main task was spreading propaganda and conducting espionage. A new variant of this strategy has been applied on a large scale by Beijing in Taiwan and Hong Kong (just before the British colony was handed over to the Chinese authorities), in order to expand its influence. According to many regional leaders and researchers, this strategy was also applied in Singapore. This is one reason why Lee Kuan Yew, the first prime minister of Singapore, during his first visit to China in 1976 conducted talks in English to prove to the international community that the country he was representing was independent and free of Chinese influence (Nahui).

Due to the fact that Singapore is located on the South China Sea, and its economy is based largely on trade with China, it should not be surprising that they are both the largest export and import partner (Singapore: Trade Statistics). According to 2017 data, Singapore is China's ninth largest trading partner, which is an impressive result if we consider the country's relatively small area. Both parties have also signed a Free Trade Agreement on October 28, 2008, which complements the similar China-ASEAN agreement from November 2002. Due to the transparency of the legal system and high economic freedom, Singapore is the second, just after Hong Kong, source of direct foreign investment in China, which is third in terms of the largest recipients of FDI (China: Foreign Investment). Singapore has actively supported the "One Belt, One Road" initiative from the very moment of its announcement, and from December 2015 it has been part of the Asian Infrastructure Investment Bank (AIIB), established to expand infrastructure in the Asia-Pacific region. Economic data shows a very large degree of dependence between these countries, and the withdrawal of the US from the TPP may only cause an increase in Chinese influence. Geographical proximity, cultural similarities, the development of advanced technologies, and huge financial outlays may completely subordinate Singapore to the government in Beijing. The South China Sea is a crucial element in the region from the point of view of strategy and of relations between China and Singapore. Through this body of water over $30 \%$ of world goods are transported, valued at $\$ 5.3$ trillion. The most important of them are, of course, energy resources (Fisxer). Securing the transport of crude oil within this basin is part of China's strategic security, because as much as $82 \%$ of this raw material is delivered by sea (Hsu). The resolution of the conflict over the disputed areas is additionally hampered by large deposits of energy resources in the seabed. According to estimates, there are 11 billion barrels of oil and 190 trillion cubic feet of natural gas below the sea floor, and under the United Nations Convention on the Law of the Sea from 1982, each country has the right to extract resources from its exclusive economic zone, which extends 200 nautical miles from its coast (Contested areas of South China Sea likely have few conventional oil and gas resources). As a result of the lack of unanimity 
among the ASEAN countries, especially the parties involved in the conflict, and as a result of the passive attitude of the US administration, which focuses on controlling the situation on the Korean peninsula, China will gradually strengthen its presence in the South China Sea. Moreover, thanks to the efficiency of foreign policy, which involves prolonging working process on the Code of Conduct through long negotiations with each party individually, Beijing will not allow for full integration within the ASEAN, which will help China consolidate its power in the region.

As a result of the uncertain future of the TPP, Singapore is likely to intensify its activity in an alternative form, initiated by the ASEAN, namely the Regional Comprehensive Economic Partnership (RCEP), comprised of 16 countries. ${ }^{6}$ The first idea of the RCEP appeared in November 2011 and, similarly to the TPP, it is a multilateral agreement aimed at facilitating trade between countries. Partnership members represent $39 \%$ of global GDP and 3.4 billion of population, but due to large disparities in economic development between members it will be very difficult to work out a set of universal principles. The biggest advantage of this type of multilateral agreement will be the avoidance of the noodle bowl or spaghetti bowl effect, which is the disorganization caused by the large number of bilateral agreements and large amount of different commercial regulations (Ordinario). Furthermore, the longterm effect of the RCEP will be the acceleration of the global economy, which will benefit all countries. Compared to TPP, formal requirements related to accession to RCEP are much less restrictive (e.g. legal regulations regarding the protection of intellectual property), which is both an advantage and a disadvantage of this format. This smoothes the way for potential new members wishing to join the partnership, but current members, concerned about allowing undesirable countries into their market, may not be working diligently enough towards reaching a final agreement. As in the case of the TPP, the decisive period for the RCEP will be 2019. During the November 2018 ASEAN Summit in Singapore the 2nd RCEP Summit also took place, where Chinese Prime Minister, Li Keqiang confirmed that free trade agreement is ready in $80 \%$ and the rest of details will be agreed by the end of 2019 .

\section{Conclusion}

Relations between China and Singapore will depend heavily on the relationship between China and ASEAN, because Singapore is holding the presidency of this organization in 2018. This is a perfect example of a country where the influences of the West and the East on a country clash. Until now, the authorities have

6 Among the RCEP members there are 10 ASEAN countries and 6 largest economies of the region, which include: China, India, Japan, South Korea, Australia and New Zealand. 
managed to maintain harmony between these two extremely different worldviews. Economic data proves that both China and the United States play an important role in the economy of Singapore. What is more, both English and Chinese (Mandarin) are official languages in Singapore, which is a perfect proof of the city's pragmatic attitude towards international relations. However, the policy of Donald Trump is largely focused on the internal situation in his own country, which is the main reason why the US withdrew from the TPP. Despite the DPRK-USA Singapore Summit, the North Korean nuclear threat still exists and may lead to a disruption of this balance in China's favor. Kim Jong Un has to prove through his decision-making that the process of denuclearization is accompanied by real actions that will reduce the arsenal of weapons of mass destruction. All in all, the Trans-Pacific Partnership without the participation of the United States is unable to meet its original purpose, namely to neutralize the significant Chinese influence in Asia.

The prominent politician Lee Kuan Yew in his book published in 2013 stated that the United States should have set up a multilateral partnership such as the TPP 30 years earlier in order to neutralize the growing power of China (Allison, 7 ). A statement like this indicates that Asian countries are aware of the threat posed by the strengthening position of China, while the policy of Donald Trump works in favor of the authorities in Beijing and facilitates this task. Likewise, economic protectionism may lead to a slowdown in the global economy, which will eventually come to affect the American citizens as well, and basing economic cooperation on bilateral trade agreements will contribute to the disorganization of trade due to the spaghetti bowl effect. On the other hand, China will be able to effectively use its influence to shape the RCEP in order to provide its economy with the best conditions for sustainable development. Finally, good economic relations with Singapore, which holds the presidency of ASEAN and chaired the leaders' summit in November 2018, was used by China to promote RCEP initiative and final version of Code of Conduct which will be developed by 2022.

The nuclear threat on the Korean Peninsula also favors China's policy, because in its shadow they can continue their work on artificial islands in the South China Sea. They do not feel any clear opposition from the United States, which at the moment is more concerned with the strict observance of denuclearization process and organization of the next summit. The history of the 6o-year conflict shows that the other parties involved in the dispute over the islands are not able to work out a common position within ASEAN, and force China to finally complete its work on the Code of Conduct. It seemed that the Philippines that held the presidency in ASEAN in 2017 could use the favorable verdict of the Permanent Court of Arbitration for this purpose. Thus, it gives a clear message to Beijing to continue pursuing policies towards each country whose main goal is to prevent the unification of the association. Each exemption from declarations made by Kim Jong 
Un on the denuclearization of North Korea may result in increased military engagement of the United States in Asia, but it will probably be concentrated only in the vicinity of Japan. The risk of any actions by the US Navy in the South China Sea will be effectively prevented by the cabbage strategy ${ }^{7}$ used by China. However, it is very likely that other countries from this region will not approve of an increased US presence in South China Sea, fearing further escalation of the conflict.

\section{Works Cited}

Allen, M. America's first Pacific president. "Politico" (November, 2009). Web. 5 January 2018, https://www.politico.com/story/2009/11/americas-first-pacific -president-029511.

Allison, G., Blackwill R.D., Wyne A. Lee Kuan Yew. The Grand Master's Insights on China, the United States, and World, Cambridge (2013), p. 7.

Basaldú, R.J. Two Eagles, One Dragon: Asymmetric Theory and the Triangular Relations between the US, China and Mexico (May, 2011). Web. 5 January 2018, https://baylor-ir.tdl.org/baylor-ir/bitstream/handle/2104/8116/Robert_Basaldu_ masters.pdf? sequence $=3$.

Belt and Road Basics, (2014). Web. 5 January 2018, https://beltandroad.hktdc.com/ en/belt-and-road-basics.

Bisley, N., Cook, M. Contested Asia and the East Asia Summit, "Perspective" (08/2016), no. 46 , pp. $1-3$.

Blackwill, R.D., Rhappleye, T. Trump's Five Mistaken Reasons for Withdrawing from the Trans-Pacific Partnership. "Foreign Policy" (June, 2017). Web. 5 January 2018, http://foreignpolicy.com/2017/06/22/trumps-five-mistaken-reasons-forwithdrawing-from-the-trans-pacific-partnership-china-trade-economics/.

Blanchard, B. China lodges protest after Trump call with Taiwan president. "Reuters" (December, 2016). Web. 5 January 2018, https://www.reuters.com/article/us-usatrump-taiwan/china-lodges-protest-after-trump-call-with-taiwan-presidentidUSKBN13R2NT?il=0.

Calamur, K. A Short History of 'America First'. “The Atlantic” (January, 2017). Web 5 January 2018, https://www.theatlantic.com/politics/archive/2017/01/ trump-america-first/514037/.

Cao, J. CAO: China's salami-slicing strategy. “The Washington Times” (June, 2014). Web 5 January 2018, https://www.washingtontimes.com/news/2014/jun/16/ cao-chinas-salami-slicing-strategy/.

7 Cabbage strategy is being described as way to block the access to contested area at sea by surrounding it with many boats - fishermen, fishing administration ships, marine surveillance ships, navy warships etc. 
Chadran, N., Tan, C. North Korea issue is 'different this time', warns Singapore prime minister. CNBC, (October, 2017). Web. 5 January 2018, https://www.cnbc. com/2017/10/19/singapore-prime-minister-lee-hsien-loong-on-north-korea-andtpp.html.

Clinton, H. America's Pacific Century. "Foreign Policy" (November, 2011). Web 5 January 2018, https://foreignpolicy.com/2011/10/11/americas-pacific-century/.

Contested areas of South China Sea likely have few conventional oil and gas resources. US Energy Information Administration (April, 2013). Web. 5 January 2018, https://www.eia.gov/todayinenergy/detail.php?id=10651.

Defense Cooperation (2015). Web. 8 January 2018, https://sg.usembassy.gov/wpcontent/uploads/sites/197/Fact-Sheet-Defense-and-Cooperation.pdf.

Factsheet - The Strategic Framework Agreement (2005). Web. 5 January 2018, https:/www.mindef.gov.sg/oms/imindef/press_room/official_releases/nr/2005/ jul/12jul05_nr/12jul05_fs.html.

Fifth Colum. Britannica (2018). Web. 5 January 2018, https://www.britannica.com/ topic/fifth-column.

Fisxer, M. The South China Sea: Explaining the Dispute. “The New York Times” (July, 2016). Web. 5 January 2018, https://www.nytimes.com/2016/07/15/world/asia/ south-china-sea-dispute-arbitration-explained.html.

Gady, F.S. South China Sea: US Navy Conducts Freedom of Navigation Operation. “The Diplomat" (August, 2017). Web. 5 January 2018, https://thediplomat. com/2017/08/south-china-sea-us-navy-conducts-freedom-of-navigation-operation/.

Holland, S. Trump, dogged at home, begins longest presidential Asia trip in years. "Reuters" (November, 2017). Web. 5 January 2018, https://www.reuters.com/ article/us-usa-trump-asia/trump-dogged-at-home-begins-longest-presidentialasia-trip-in-years-idUSKBN1D30A9.

Holmes, O. 'Death of democracy' in Cambodia as court dissolves opposition. “The Guardian” (November, 2017). Web. 5 January 2018, https://www.theguardian. com/world/2017/nov/16/death-of-democracy-cambodia-court-dissolvesopposition-hun-sen.

Hsu, S. China's Energy Insecurity Glaring In South China Sea Dispute. "Forbes" (September, 2016). Web. 5 January 2018, https://www.forbes.com/sites/sarahsu/2016/09/02/ china-energy-insecurity-south-china-sea-dispute/\#6389908e2eec.

Hufbauer, G.C. The Evolving US View on TPP, "Working Paper" (10/2013), vol. 484, p. 3. Web. January 5 2018, https://globalpoverty.stanford.edu/sites/default/files/ publications/484wp.pdf.

Miller, T., Kim, A.B. 2017 Index of Economic Freedom. Institute For Economic Freedom (2017). Web. 5 January 2018, http://www.heritage.org/ index/pdf/2017/ book/index_2017.pdf. 
Mullen, J. China is America's biggest creditor once again. CNN Money (August, 2017). Web. 5 January 2018, http://money.cnn.com/2017/08/16/investing/china-us-debttreasuries/index.html.

Nahui, C. Li Xue, Lee Kuan Yew's Legacy for China-Singapore Relations. “The Diplomat” (December, 2016). Web. 5 January 2018 https://thediplomat. com/2016/12/lee-kuan-yews-legacy-for-china-singapore-relations/.

Ordinario, C. RCEP 'mega trade deal', FTAs to boost trade, investments in Asia, Pacific-ADB. "Business Mirror" (October, 2017). Web. 5 January 2018, https:// businessmirror.com.ph/rcep-mega-trade-deal-ftas-to-boost-trade-investmentsin-asia-pacific\%C2\%AD\%C2\%AD-adb/.

Perlez, J. Tribunal Rejects Beijing's Claims in South China Sea. "The New York Times" (July, 2016). Web. 5 January 2018, https://www.nytimes.com/2016/07/13/world/ asia/south-china-sea-hague-ruling-philippines.html.

Population Trends (2017). Web. 5 January 2018, http://www.singstat.gov.sg/docs/ default-source/default-document-library/publications/publications_and_papers/ population_and_population_structure/population2017.pdf.

Singapore Free Trade Agreements (2012). Web. 5 January 2018, https://www. iesingapore.gov.sg/Trade-From-Singapore/International-Agreements/free-trade -agreements/Singapore-FTA.

Singapore: Trade Statistics. "Global Edge” (2017). Web. 5 January 2018, https:// globaledge.msu.edu/countries/singapore/tradestats.

Trade in Goods with China, United States Census Bureau (2017). Web. 5 January 2018, https://www.census.gov/foreign-trade/balance/c5700.html.

US and China sign trade deals worth $\$ 250$ bn on Trump trip as he vows to change 'unfair' relationship. "Independent” (November, 2017). Web. 5 January 2018, http://www.independent.co.uk/news/business/news/trump-china-trade-beijingxi-jinping-250-billion-a8045061.html.

US Election 2016: Asia markets jolted by Trump win. BBC (November, 2016). Web. 5 January 2018, http://www.bbc.com/news/business-37917842.

$\mathrm{Vu}, \mathrm{K}$. Vietnam becomes seventh country to ratify Trans-Pacific trade pact. "Reuters" (November 2018). Web. 20 December 2018, https://www.reuters.com/article/ustrade-tpp/vietnam-becomes-seventh-country-to-ratify-trans-pacific-trade-pactidUSKCN1NHOVF.

Woo, S. Triangle Research and Understanding Northeast Asia Politics. "Asia Perspective" (2003), vol. 27, no. 2, pp. 34-36.

YingHui, L. A South China Sea Code of Conduct: Is Real Progress Possible? “The Diplomat" (November, 2017). Web. 5 January 2018, https://thediplomat. com/2017/11/a-south-china-sea-code-of-conduct-is-real-progress-possible/.

Zhou, P. Singapore's Economic Development. ThoughtCo. (April, 2018). Web. 5 January 2018, https://www.thoughtco.com/singapores-economic-development-1434565. 
Mateusz Chatys - graduate of the Faculty of International and Political Studies at the University of Lodz, Oriental specialty. Student of third-degree studies in political sciences at the Department of East Asia, Faculty of International and Political Studies at the University of Lodz. Active member of the Student Scientific Circle of East Asia and the Pacific, as well as scholarship holder of the EU Window Chinese Government Scholarship program in China at Hainan University in 2015. Leader of the volunteer team during the first edition of summer school for students from China, Understanding Poland: Economy, Society and Science in Lodz in 2017. 